\title{
Effects of the aqueous extract from Hyptis pectinata leaves on rodent central nervous system
}

\author{
Alexsandro X. Bueno ${ }^{1}$, Alisson T.S. Moreira ${ }^{1}$, Flávia T. Silva ${ }^{2}$, Charles S. Estevam ${ }^{1}$, \\ Murilo Marchioro ${ }^{1 *}$ \\ ${ }^{1}$ Laboratório de Neurofisiologia, Departamento de Fisiologia, Universidade Federal de Sergipe, 49100-000, São \\ Cristóvão, SE, Brazil, \\ ${ }^{2}$ Laboratório de Fisiologia Comportamental, Departamento de Fisiologia, Universidade Federal de Sergipe, \\ 49100-000, São Cristóvão, SE, Brazil
}

\begin{abstract}
RESUMO: "Efeitos do extrato aquoso das folhas da Hyptis pectinata sobre o sistema nervoso central de roedores". Neste trabalho foram estudados os efeitos do extrato aquoso (EA) obtido das folhas da Hyptis pectinata sobre o sistema nervoso central de roedores. Os seguintes modelos experimentais foram utilizados em camundongos, machos e fêmeas, da linhagem Wistar: "screening" farmacológico, campo aberto, nado forçado, hipotermia induzida por apomorfina, labirinto em cruz elevado e tempo de sono induzido por tiopental. $\mathrm{O}$ extrato foi administrado por via oral em dose única, 30 minutos antes de cada teste. No "screening" farmacológico o EA (400 mg/kg, p.o., n =3) diminuiu a freqüência do comportamento de auto-limpeza. No teste do campo aberto o EA diminuiu o tempo gasto em auto-limpeza (AE400: 51,3 $\pm 8,8, \mathrm{q}=5,513, \mathrm{P}<0.01, \mathrm{n}=10$ ) de maneira similar ao diazepam (control: 107,3 $\pm 14,2$; diazepam: 15,4 $\pm 4,3, \mathrm{q}=9,049, \mathrm{P}<0.001, \mathrm{n}$ $=10)$. No teste do nado forçado o EA $(400 \mathrm{mg} / \mathrm{kg}$ ) diminuiu o tempo de imobilidade (con: 181,3 \pm 7,2 s; imip: 91,6 $\pm 8,9 \mathrm{~s}, \mathrm{q}=7,958, \mathrm{P}<0,001$; AE400: 111,6 $\pm 14,5 \mathrm{~s}, \mathrm{q}=6,193, \mathrm{P}<0,001, \mathrm{n}=9$ ) indicando um possível efeito antidepressivo. Isto foi confirmado no modelo de hipotermia induzida pela apomorfina onde o EA $(200 \mathrm{mg} / \mathrm{kg})$ antagonizou o efeito da apomorfina (AE200: $-0,27^{\circ} \mathrm{C}, \mathrm{q}=$ $5,588, \mathrm{P}<0,001, \mathrm{n}=10)$ de maneira similar à imipramina $(5 \mathrm{mg} / \mathrm{kg})$ (control: $-1,08^{\circ} \mathrm{C}$; imipramine: $\left.0,02{ }^{\circ} \mathrm{C}, \mathrm{q}=7,589, \mathrm{P}<0,001, \mathrm{n}=10\right)$. Nenhum efeito do EA foi observado nos testes do labirinto em cruz elevado e do tempo de sono induzido por tiopental. Nossos resultados sugerem um possível efeito antidepressivo do extrato aquoso obtido das folhas da Hyptis pectinata.
\end{abstract}

Unitermos: Hyptis pectinata, Lamiaceae, plantas medicinais, depressão.

\begin{abstract}
The effects of the aqueous extract (AE) from Hyptis pectinata leaves was studied on rodent central nervous system (CNS). Pharmacological screening, open field, forced swimming, apomorphine-induced hypothermia, elevated plus maze and thiopental-induced sleep tests were used in male and female Swiss mice and Wistar rats. The AE was admnistered orally in single doses 30 minutes before each test. In the screening test the AE $(400 \mathrm{mg} / \mathrm{kg}, \mathrm{p} . \mathrm{o} ., \mathrm{n}=3)$ decreased the frequency of grooming behavior. In the open field test it decreased the amount of time rats spent grooming (AE400: $51.3 \pm 8.8, \mathrm{q}=5.513, \mathrm{P}<0.01, \mathrm{n}=10$ ), similarly to diazepam (control: $107.3 \pm$ 14.2; diazepam: $15.4 \pm 4.3, \mathrm{q}=9.049, \mathrm{P}<0.001, \mathrm{n}=10)$. In the forced swimming test the $\mathrm{AE}(400$ $\mathrm{mg} / \mathrm{kg}$ ) decreased the immobility time (con: $181.3 \pm 7.2 \mathrm{~s}$; imip: $91.6 \pm 8.9 \mathrm{~s}, \mathrm{q}=7.958, \mathrm{P}<0.001$; AE400: $111.6 \pm 14.5 \mathrm{~s}, \mathrm{q}=6.193, \mathrm{P}<0.001, \mathrm{n}=9$ ), indicating a possible antidepressive effect. This was confirmed in the apomorphine-induced hypothermia model where the extract $(200 \mathrm{mg} / \mathrm{kg})$ antagonized the apomorphine effect (AE200: $-0.27^{\circ} \mathrm{C}, \mathrm{q}=5.588, \mathrm{P}<0.001, \mathrm{n}=10$ ), similarly to imipramine (imipramine: $5 \mathrm{mg} / \mathrm{kg}$ ) (control: $-1.08{ }^{\circ} \mathrm{C}$; imipramine: $0.02{ }^{\circ} \mathrm{C}, \mathrm{q}=7.589, \mathrm{P}<0.001, \mathrm{n}$ $=10$ ). No effect of the AE was detected in the elevated plus maze and in the sleeping time induced by thiopental models. Our results suggest a possible antidepressive effect of the aqueous extract obtained from the leaves of Hyptis pectinata.
\end{abstract}

Keywords: Hyptis pectinata, Lamiaceae, medicinal plants, depression

\section{INTRODUCTION}

Hyptis pectinata (L.) Poit, is a shrub belonging to the Lamiaceae family popularly known in northeastern Brazil as "sambacaitá". It is commonly cultivated in the backyards of many Brazilian houses where the plant is used as an analgesic and antiinflammatory preparation obtained from its leaves by decoction or infusion. (Carvalho, 1999; Arrigoni-Blank et al., 2005; Falcão et al., 2005). H. pectinata is also described in Brazilian folk medicine for the treatment of rhinopharyngitis, nasal congestion, skin diseases, fever, bacterial and fungi 
infections (Malam et al., 1988;).

Phytochemical studies of $H$. pectinata identified the compound 5,6-dihidro- $\alpha$-pirona followed by other pectinolides which showed activity against Staphylococcus aureus and Bacillus subtilis and citotoxicity against a variety of tumoral cells (PeredaMiranda et al., 1993). The essential oil of $H$. pectinata contains around thirty compounds with a predominance for the monoterpenes $(95.8 \%)$, the most abundant one being $\rho$-cimene, thymol and $\beta$-terpinene. The antipseptical properties of the plant probably are related to its high concentrations of thymol (Malan et al., 1988).

The aqueous extract from the $H$. pectinata leaves was investigated for its antinociceptive and antioedematogenic properties. The extract showed positive results on the abdominal contortions and hot plate analgesy models and antinflammatory activity in the paw oedema model (Bispo et al., 2001; Arrigoni-Blank et al., 2005; Falcão et al., 2005). The same laboratory demonstrated that the aqueous extract of $H$. pectinata accelerated liver regeneration after hepatectomy in rats (Melo et al., 2005). Another species of Hyptis, for instance, $H$. martiusii, common in the northeast of Brazil, showed activity against larvae of Aedes aegypti (Costa et al., 2005).

The aim of the present work was to study the central effects of the aqueous extract from the leaves of H. pectinata.

\section{MATERIAL AND METHODS}

\section{Botanical material}

Hyptis pectinata was collected at the metropolitan area of Aracaju city at the state of Sergipe, Brazil $\left(10^{\circ} 54^{\prime} \mathrm{S}, 37^{\circ} 05^{\prime} \mathrm{W}\right)$. A voucher specimen of the plant was deposited at the Universidade Federal de Sergipe (UFS) herbarium under the number ASE 2626.

\section{Preparation of the extract}

Dried $H$. pectinata leaves were triturated until a fine powder was obtained. The aqueous extract (AE) was prepared by adding distilled water $(3: 10 \mathrm{w} / \mathrm{v})$ and mantaining the solution in constant agitation for four hours at $35{ }^{\circ} \mathrm{C}$, followed by filtration. The $\mathrm{AE}$ was then lyophilized and stored at $5{ }^{\circ} \mathrm{C}$. At the day of each experiment the $\mathrm{AE}$ was dissolved in distilled water at the desired doses.

\section{Animals}

The experiments described in this work followed the ethical rules established by the UFS Ethical Comitte for Animal Experimentation (CEPA-UFS). We used male and female Swiss mice (20-35 g) and Wistar rats $(250-350 \mathrm{~g})$ from the UFS Animal Facility. Animals were maintained in a 12 hours dark-light cycle at room temperature with water and Purina tablets available ad libitum. They were housed in groups of 10 mice or 5 rats in plastic boxes $(33 \times 40 \times 7 \mathrm{~cm})$.

\section{Behavioral tests}

Pharmacological screening: This test was used in order to check for possible general central nervous system effects of the $H$. pectinata AE. Four groups of three mice were treated with distilled water $(10 \mathrm{~mL} / \mathrm{kg}$, p.o.) or the $\mathrm{AE}$ at the doses of 100,200 and $400 \mathrm{mg} / \mathrm{kg}$ (p.o., at a single dose). Animals were observed for four hours and their behavior were recorded at 30,60, 120, 180 and 240 minutes after the treatment. The specific behaviors and their intensities were recorded, according to Irwin (1968).

Open field: The exploratory activity of rats treated with the AE was tested in the open field model. The apparatus consists of a square box made of wood (60 x $60 \times 30 \mathrm{~cm}$ ) with the floor divided by black lines into nine $20 \mathrm{~cm}$ squares. The box was illuminated from above by fluorescent light and recorded by a microcamera. Five groups of ten rats received distilled water $(10 \mathrm{~mL} / \mathrm{kg}$, p.o.), diazepam (2 mg/kg, i.p.) or the $\mathrm{AE}$ at the doses 100,200 and $400 \mathrm{mg} / \mathrm{kg}$ (p.o., at a single dose). The distilled water group and the AE groups received also i.p. injections of saline $(0.9 \%)$ and the diazepam group received also distilled water (p.o.) in order to normalize the treatments. Thirty minutes after each treatment animals were exposed to five minutes session in the open field and the following parameters were recorded: total distance travelled, number of rearings and grooming time. Data were acquired and analised by the ANYMZE software (Stoelting Co., USA).

Forced swimming test: To test for possible antidepressive effects of the $H$. pectinata $\mathrm{AE}$ we used the forced swimming test as proposed by Porsolt et al. (1977). The apparatus consists of a square glass aquarium $\left(25 \times 30 \mathrm{~cm}\right.$ ) filled with $15 \mathrm{~cm}$ of tap water at $24{ }^{\circ} \mathrm{C}$. Five groups of ten mice received distilled water $(10 \mathrm{~mL} / \mathrm{kg}$, p.o), imipramine $(30 \mathrm{mg} / \mathrm{kg}$, i.p.) and the $\mathrm{AE}$ at the doses of 100,200 and $400 \mathrm{mg} / \mathrm{kg}$ (p.o., at single doses). The distilled water group and the $\mathrm{AE}$ groups received also i.p. injections of saline $(0.9 \%)$ and the imipramine group received also distilled water (p.o.) in order to normalize the treatments. Each animal was placed in the aquarium for six minutes and the immobility time was recorded with a stop watch during the last four minutes of the session. Animals were considered immobile when their movements were sufficient only to prevent them from drawning.

\section{Apomorphine-induced hypothermia}

Apomorphine treatment causes a decrease in the rectal temperature and this effect is prevented by 
antidepressive drugs such as imipramine (Puech et al., 1981). In order to confirm a possible antidepressive effect of the $H$. pectinata AE, we tested the effects of apomorphine in rectal temperature of mice treated with the plant AE. Five groups of ten mice received distilled water $(10 \mathrm{~mL} / \mathrm{kg}$, p.o $)$, imipramine $(30 \mathrm{mg} / \mathrm{kg}$, i.p., at a single dose) and the $\mathrm{AE}$ at the doses of 100, 200 and 400 $\mathrm{mg} / \mathrm{kg}$ (p.o., at single doses). Before treatments rectal temperature was measured with a digital termometer introduced $15 \mathrm{~mm}$ in the rectum. Animals with temperatures between 37 and $38,4{ }^{\circ} \mathrm{C}$ were treated with distilled water, imipramine or the $\mathrm{AE}$ and thirty minutes after they were injected with apomorphine $(10 \mathrm{mg} / \mathrm{kg}$, i.p., at a single dose). One hour after, temperature was measured again and compared with the initial values.

Elevated plus maze (EPM): The EPM test, originally developed by Pellow et al. (1985), was used in this work to check the anxiety level of rats treated with the $H$. pectinata AE. The maze was made of wood with two open and closed arms $(50 \times 10 \mathrm{~cm})$ elevated $50 \mathrm{~cm}$ from the floor. Five groups of ten rats received distilled water (10 mL/kg, p.o.), diazepam ( $2 \mathrm{mg} / \mathrm{kg}$, i.p., at a single dose) or the AE at the doses 100, 200 and 400 $\mathrm{mg} / \mathrm{kg}$ (p.o., at single doses). Thirty minutes after each treatment animals were exposed to five minutes sessions in the EPM and the following parameters were recorded: percentage of time spent in the open and closed arms and percentage of open and closed arm entries. The behavior of animals was monitored by a microcamera located $2 \mathrm{~m}$ above the maze and data were acquired and analised by the ANYMAZE software.

Thiopental-induced sleeping time: According to Riley and Spinks (1958) CNS depressive drugs increase barbiturate-induced sleeping time. In this work we used tiopental as a sedative drug and checked the effcts of $H$. pectinata AE. Four groups of 10 mice received distilled water $(10 \mathrm{~mL} / \mathrm{kg}$, p.o. $)$ or the AE at single doses of 100 , 200 and $400 \mathrm{mg} / \mathrm{kg}$ (p.o.) thirty minutes before an i.p. injection of tiopental $(80 \mathrm{mg} / \mathrm{kg})$. The time for loosing (latency for sleeping) and recovering (sleeping duration) the rightining reflex was recorded for each animal. The loosing of the postural reflex was confirmed after three atempts.

\section{Drugs}

The drugs used in this work were: diazepam (Cristália, Brasil), imipramine hydrochloride (Farmafórmula, Brasil) and apomorphine hydrochloride (Sigma, USA) were dissolved in saline (0.9\%) just before each experiment.

\section{Statistical analysis}

Data were expressed as the mean \pm SEM, except for the apomorphine-induced hypothermia experiment where the values were expressed as the mean difference of temperature before and after apomorphine treatment. One way analysis of variance (ANOVA) followed by Tukey' multiple comparison test were used to evaluate difference among means. Values of $\mathrm{P}<0.05$ were considered significant.

\section{RESULTS}

In the pharmacological screening the only noticeble effect of the $H$. pectinata $\mathrm{AE}$ was a decrease in the frequency of grooming behavior at the dose of $400 \mathrm{mg} / \mathrm{kg}$ when compared to control mice. In the open field test one way ANOVA revealed difference for the parameters total distance travelled $\left(\mathrm{F}_{4,45}=11.410, \mathrm{p}<\right.$ $0.001)$ and grooming time $\left(\mathrm{F}_{4,45}=11.440, \mathrm{P}<0.001\right)$, among the experimental groups (table 1). The multiple comparison Tukey post test showed that diazepam (2 $\mathrm{mg} / \mathrm{kg})$ increased the distance travelled $(\mathrm{q}=7.565, \mathrm{P}$ $<0.001)$ and that the $H$. pectinata AE had no effect in this parameter when compared to control (AE100: $\mathrm{q}=$ 1.530; AE200: $\mathrm{q}=1.228$; AE400: $\mathrm{q}=1.711 ; \mathrm{P}>0.05)$. Diazepam decreased the time rats spent grooming (con: $107.3 \pm 14.2$; diaz: $15.4 \pm 4.3, \mathrm{q}=9.049, \mathrm{P}<0.001)$, an effect that was also observed for the $\mathrm{AE}$ at the dose of 400 $\mathrm{mg} / \mathrm{kg}$ (AE400: $51.3 \pm 8.8, \mathrm{q}=5.513, \mathrm{P}<0.01$ ).

In the forced swimming test ANOVA revealed statistical differences among the experimental groups $\left(\mathrm{F}_{4,40}=15.810, \mathrm{P}<0.001\right)$. As expected, imipramine (30 $\mathrm{mg} / \mathrm{kg}$ ) decreased the immobility time as shown by the Tukey post test (control: $181.3 \pm 7.2$; imip: $91.6 \pm 8.9$, $q=7.958, P<0.001)$. The same effect was seem for the $\mathrm{AE}$ at the dose of $400 \mathrm{mg} / \mathrm{kg}$ (AE400: $111.6 \pm 14.5, \mathrm{q}=$ $6.193, \mathrm{P}<0.001$ ) (Figure 1).

In the apomorphine-induced hypothermia test ANOVA revealed difference in the temperature reduction among the experimental groups $\left(\mathrm{F}_{4,45}=12.940, \mathrm{P}<\right.$ $0.0001)$. Imipramine $(5 \mathrm{mg} / \mathrm{kg})$ inhibited the apomorphine effect, as shown by the Tukey as a pos hoc test (control: $-1.08^{\circ} \mathrm{C}$; imip: $0.02^{\circ} \mathrm{C}, \mathrm{q}=7.589, \mathrm{P}<0.001$ ). The same effect was seen with the $\mathrm{AE}$ at the dose of $200 \mathrm{mg} / \mathrm{kg}$ (AE200: $-0.27{ }^{\circ} \mathrm{C}, \mathrm{q}=5.588, \mathrm{P}<0.001$ ), but not for the doses of 100 and $400 \mathrm{mg} / \mathrm{kg}$ (AE100: $-0.73^{\circ} \mathrm{C}, \mathrm{q}=2.415$; AE400: $-1.2^{\circ} \mathrm{C}, \mathrm{q}=0.827 ; \mathrm{P}>0.05$ ) (Figure 2). The $H$. pectinata AE did not show effects on the elevated plus maze nor on the tiopental-induced sleeping tests (data not shown).

\section{DISCUSSION}

In this work we studied the central effects of the AE from Hyptis pectinata leaves. The most important finding was an antidepressive effect as revealed by the forced swimming and apomorphine-induced hypothermia tests.

A general pharmacological screening with the $H$. pectinata $\mathrm{AE}$ did not reveal major effects on the nervous system, with the exception of a decrease in 
Table 1. Effects of the Hyptis pectinata AE on the behavior of rats in the open field model.

\begin{tabular}{|c|c|c|c|}
\hline Group/Dose/n & Total distance travelled $(\mathrm{m})$ & Grooming time $(\mathrm{s})$ & Number of rearings \\
\hline Control(Water) $(10 \mathrm{~mL} / \mathrm{kg})(10)$ & $6.78 \pm 0.9$ & $107.3 \pm 14.2$ & $7.8 \pm 1.2$ \\
\hline Diazepam $(2 \mathrm{mg} / \mathrm{kg})(10)$ & $17.4 \pm 2.0^{* * *}$ & $15.4 \pm 4.3^{* * * *}$ & $14.3 \pm 1.38$ \\
\hline Hyp100 (100 mg/kg) (10) & $8.9 \pm 0.9$ & $79.4 \pm 10.7$ & $11.3 \pm 1.63$ \\
\hline Нyp200 (200 mg/kg) (10) & $5.0 \pm 1.1$ & $73.7 \pm 10.7$ & $6.8 \pm 2.49$ \\
\hline Hyp400 (400 mg/kg) (10) & $9.19 \pm 1.6$ & $51.3 \pm 7.9^{* * *}$ & $8.8 \pm 2.5$ \\
\hline
\end{tabular}

Each animal was allowed to explore the arena during a period of five minutes. Values were expressed as the mean \pm S.E.M. The differences among means were tested by one way Analysis of Variance (ANOVA) followed by Tukey multiple comparison post test. (**) $\mathrm{P}<0.01 ;(* *) \mathrm{P}<0.001$ as compared to control.

time spent in the grooming behavior, which leads us to further exploration of this effect. In the open field model, the $\mathrm{AE}$ also decreased the time spent grooming (table $1)$, an effect also observed with diazepam $(2 \mathrm{mg} / \mathrm{kg})$, a classical benzodiazepine drug. Benzodiazepines, at lower doses, are known to increase the exploratory activity in the open field (Gardner; Piper, 1982) and to decrease the time spent grooming (Jolles et al., 1979). Although the physiological meaning of the grooming behavior is still a matter of debate, some authors suggest that it is related to body temperature regulation (Thiessen, 1988) or it is possibly a way for decreasing the excitation caused by exposure to a novel environment (Colbern et al., 1978). More interestingly, an involvement of the mesolimbic dopamine system in novelty-induced grooming has been proposed (D'Aquila et al., 1994).

The effects of desipramine, a tryciclic antidepressant, were tested for the exploratory behaviour and grooming in the open field, under different stress protocols. Repeated restraint stress was shown to increase the frequency of grooming and desipramine reversed this effect (D'Aquila et al., 2000). Moreover, Sousa et al. (2004) described antianxiety and antidepressive effects of riparin III, a tyramine analogue isolated from Aniba riparia. In the open field test, riparin III ( 25 and $50 \mathrm{mg} / \mathrm{kg}$ ) decreased the number of groomings and the immobility time in the forced swimming model.Therefore, it seems that grooming behavior in the open field can be a predictor for antidepressant activity, possibly via the dopaminergic mesolimbic system (D'Aquila et al., 2000).

Stressfull events are frequently associated with depression and HPA activity is positively correlated with depressive symptoms (Anisman; Zacharco, 1982). Van-Erp et al. (1994) demonstrated a direct relationship between the frequency of groomings and corticosteroid levels in rodents. We used two experimental models to check for possible antidepressive effects of the $H$. pectinata $\mathrm{AE}$. The $\mathrm{AE}$ decreased the immobility time in the forced swmming test (figure 1) and reversed the hypothermia induced by apomorphine (figure 2).
These effects were similar to those of imipramine, a classical antidepressant drug, suggesting that the effect of the AE on grooming behavior is possibly linked to an antidepressive property of the $H$. pectinata leaves. On the other hand the AE did not interfered with the behaviour of rats in the elevated plus maze. Clinical studies have demonstrated a high correlation between depression and anxiety (Keller; Hanks, 1993, File, 1996), suggesting common neurobiological substrates for these diseases. However, results using animal models are conflicting. Ferré et al. (1994) found a high correlation between the immobility time in the forced swimming test and the latency for entering in the open arm of the elevated plus maze test, but Andreatini and Bacellar (1999) studying the behaviour of mice tested in the two models found no significant correlation. Similarly to $H$. pectinata, Kielmeyera coriacea shows anxiolytic properties which were confirmed in the elevated plus maze but showed no effect in the forced swimming test (Audi et al., 2002). Differently, the extract from Hypericum perforatum showed antidepressive and anxiolytic effects in a variety of experimental models (Di Carlo et al., 2001). The elucidation of mechanisms of action of the $H$. pectinata $\mathrm{AE}$ in the future will clarify its differential effects on animal models of depression and anxiety.

Inverted U-shaped dose-response curves are frequently found with plant crude extracts. Thus, Maity et al. (2000) testing the methanol root extract from Ocimum sanctum in the forced swimming test found a significant decrease in the duration of swimming with lower doses $(100$ and $200 \mathrm{mg} / \mathrm{kg}$ ) and an increase of this parameter with higher doses $(400 \mathrm{mg} / \mathrm{kg})$. In our laboratories, the aqueous and hydroalcaholic extracts from Erythrina velutina leaves showed anxiolytic and amnesic effects at lower doses and inhibition of locomotor activity and prolongation of barbiturate sleeping at higher doses (Dantas et al., 2004). In the apomorphine-induced hypothermia test the $H$. pectinata AE reversed the effect of apomorphine at the dose of $200 \mathrm{mg} / \mathrm{kg}$. At 100 and $400 \mathrm{mg} / \mathrm{kg}$ the scores were not different from the control 


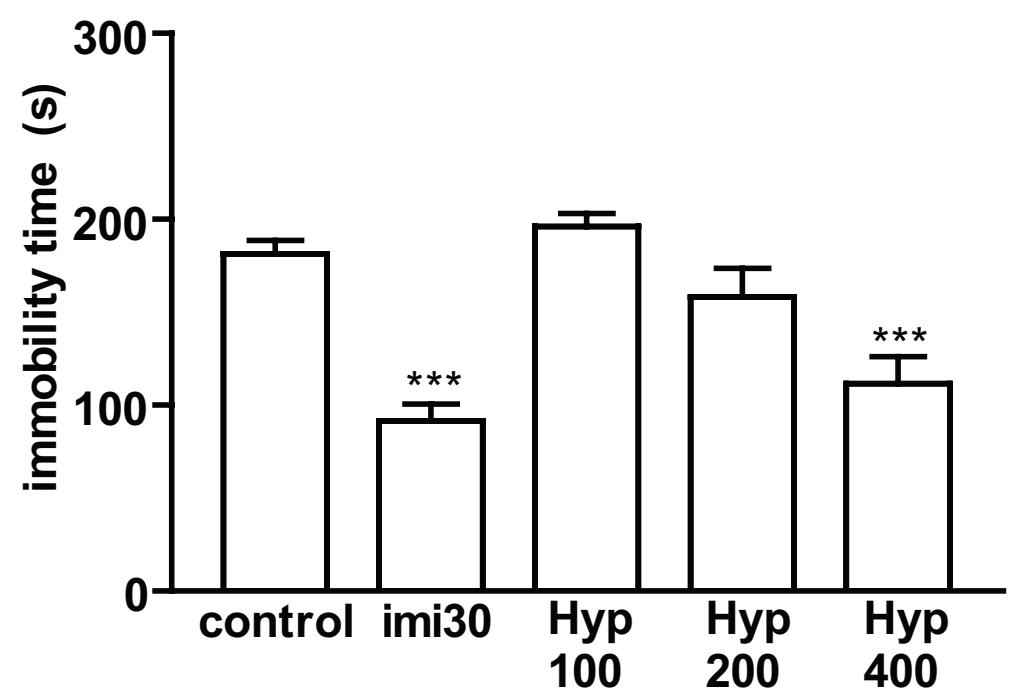

Figure 1. Effects of the $H$. pectinata $\mathrm{AE}$ in the immobility time on the forced swimming test. Hyp100, Hyp200 and Hyp400 refers to the dose of the extract used (100, 200 and 400 $\mathrm{mg} / \mathrm{kg}$, p.o.). At the dose of $400 \mathrm{mg} / \mathrm{kg}$ the AE showed similar effects to the imipramine group (imi30 refers to imipramine $30 \mathrm{mg} / \mathrm{kg}$, i.p.). $* * * \mathrm{P}<0.001$ as compared to control, Tukey post test after one way ANOVA.

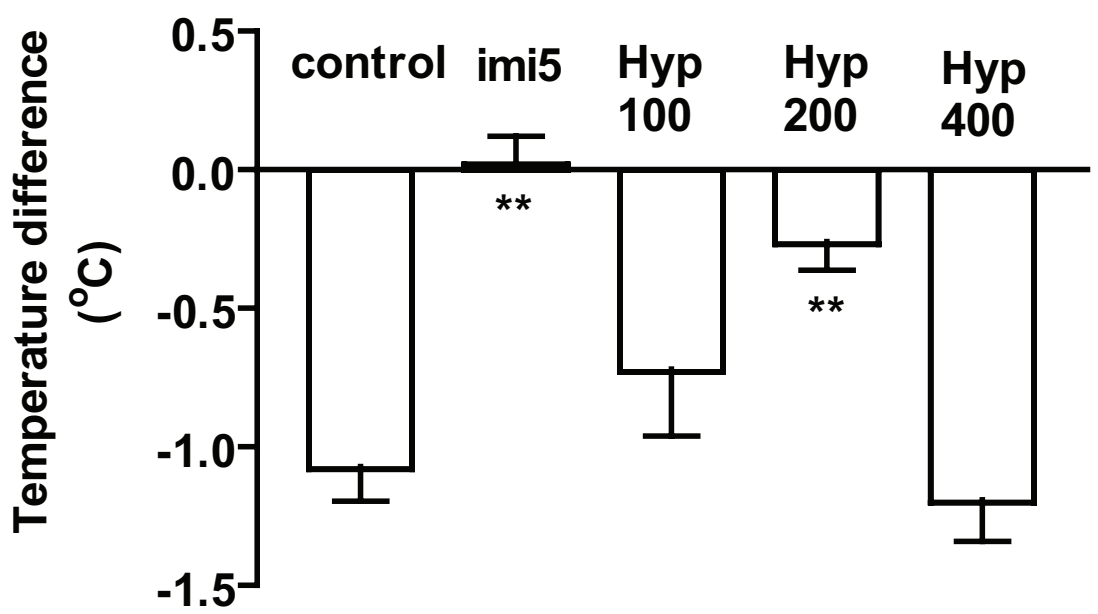

Figure 2. Effects of the $H$. pectinata $\mathrm{AE}$ on the apomorphine-induced hypothermia test. Values are expressed as the difference in rectal temperature before and one hour after an i.p. injection of apomorphine. At the dose of $200 \mathrm{mg} / \mathrm{kg}$, p.o., the AE (Hyp200) showed similar effects to the imipramine group (imi5 refers to imipramine $5 \mathrm{mg} / \mathrm{kg}$ ). $* * \mathrm{P}<0.001$, as compared to control (distilled water) by the Tukey post test after one way ANOVA.

group. This biphasic effect most likely is due to different classes of compounds found in the crude extract (Mendes et al., 2002). At noradrenergic terminals apomorphine acting through $\mathrm{D}_{2}$ receptors prevents noradrenaline release. Puech et al. (1981) showed that hypothermia induced by high doses of apomorphine is antagonized by antidepressants.

Different animal models often require different doses of the same drug, in order to show any effect. This is because they probably measure different aspects of the same disease. That possibly explains the difference in doses for the AE on the two models of depression. Support for this hypothesis was found in the work of Sousa et al. (2004) where the tryciclic antidepressant imipramine decreased the immobility time in the tail supension test at a higher dose $(30 \mathrm{mg} / \mathrm{kg})$ when compared with the effect 
in the forced swimming test $(10 \mathrm{mg} / \mathrm{kg})$.

The results presented in this work will guide the screening for fractions and isolated compounds from Hyptis pectinata with potential antidepressant and/or antistress properties.

\section{AKNOWLEDGEMENTS}

This work was supported by a scholarship from CAPES-Brasil to author Bueno, A.X. and a grant from Fundação de Amparo à Pesquisa do Estado de Sergipe (FAP-SE) to author M. Marchioro.

\section{REFERENCES}

Andreatini R, Bacellar LFS 1999. The relationship between anxiety and depression in animal models: a study using the forced swimming test and elevated plus maze. Braz J Med Biol Res 32: 1121-1126.

Anisman H, Zacharko RM 1982. Depression: The predisposing influence of stress. Behl Brain Sci 5: 89-137.

Arrigoni-Blank MF, Silva-Mann R, Campos DA, Silva PA, Antoniolli AR, Caetano LC, Sant'Ana AEG, Blank AF 2005. Morphological, agronomical and pharmacological characterization of Hyptis pectinata (L.) Poit germplasm. Rev Bras Farmacogn 15: 298-303.

Audi EA, Otobone F, Martins JVC, Cortez DAG 2002. Preliminary evaluation of Kielmeyera coriacea leaves on the central nervous system. Fitoterapia 73: 517-519.

Bispo MD, Mourão RH, Franzotti EM, Bomfim KB, ArrigoniBlank MF, Moreno MP, Marchioro M, Antoniolli AR 2001. Antinociceptive and antiedematogenic effects of the aqueous extract of Hyptis pectinata leaves in experimental animals. J Ethnopharmacol 76: 81-86.

Carvalho IBM 1999. O uso popular de plantas medicinais da caatinga do povoado de Curituba: municipio de Canindé do São Francisco. São Cristóvão. Dissertação de Mestrado. Núcleo de Pós-Graduação em Estudos do Semi-árido, Universidade Federal de Sergipe.

Colbern DL, Isaacson RL, Green EJ, Green EJ 1978. Repeated intraventricular injections of ACTH 1-24: the effects of home or novel environments on excessive grooming. Behav Biol 23: 381-387.

Costa JGM, Rodrigues FFG, Angélico EC, Silva MR, Mota ML, Santos NKA, Cardoso ALH, Lemos TLG 2005. Estudo químico-biológico dos óleos essenciais de Hyptis martiusii, Lippia sidoides e Syzigium aromaticum frente às larvas do Aedes aegypti. Rev Bras Farmacogn 15: 304-309.

Dantas MC, Oliveira FS, Bandeira SM, Batista JS, Silva Jr. CD, Alves PB, Antoniolli AR, Marchioro M 2004. Central nervous system effects of the crude extract of Erythrina velutina leaves on rodents. $J$ Ethnopharmacol 94: 129-133.

D’Aquila PS, Colu M, Pni L, Gessa GL, Serra G 1994. Antidepressant-like effect of selective dopamine D1 receptor agonist in the behavioural despair model of depression. Eur J Pharmacol 262: 107-111.

D'Aquila PS, Peana AT, Carboni, V Serra G 2000. Exploratory behaviour and grooming after repeated restraint and chronic mild stress: effect of desipramine. Eur $J$ Pharmacol 399: 43-47.

Di Carlo G, Borrelli F, Ernest E, Izzo AA 2001. St. John's wort: Prozac from the plant kingdom. Trends Pharmacol Sci 22: 292-297.

Falcão HS, Lima IO, Santos VL, Dantas HF, Diniz MFFM, Barbosa-Filho JM, Batista LM 2005. Review of the plants with anti-inflammatory activity studied in Brazil. Rev Bras Farmacogn 15: 381-391.

Ferré P, Fernandez-Teruel A, Garcia E, Zapata A, Tobena A 1994. Struggling and flumazenil effects in the swimming test are related to the level of anxiety in mice. Neuropsychobiol 29: 23-27.

File SE 1996. Recent developments in anxiety, stress, and depression. Pharmacol Biochem Be 54: 3-12.

Gardner CR, Piper DC 1982. Effects of agents which enhance GABA-mediated neurotransmission on licking conflict in rats and exploration in mice. Eur $J$ Pharmacol 83: 25-33.

Irwin S. 1968. A systematic quantitative procedure for assessing the behavioral and physiologic state of the mouse. Psychopharmacology 13: 222-257.

Jolles J, Rompa-Barendregt J, Gispen WH 1979. Novelty and grooming behavior in the rat. Behav Neural Biol 25: 563-572.

Keller MBE, Hanks DL 1993. Course and outcome in panic disorder. Prog Neuropsychopharmacol Biol Psych 17: 551-570

Maity TK, Mandal SC, Saha BP, Pal M 2000. Effect of Ocimum sanctum roots extract on swimming performance in mice. Phytother Res 14: 120-121.

Malan K, Pelissier Y, Marion C, Blaise A, Bessieri JM 1988. The essential oil of Hyptis pectinata. Planta Med 54: $531-532$

Melo GB, Silva RL, Melo VA, Lima SO, Antoniolli AR, Castro e Silva T, Marcassa LG, Bagnato VS, Zucoloto S, Ramalho LN, Ramalho FS, Castro e Silva OJr. 2005. Enhancement of liver regenerationby the association of Hyptis pectinata with laser therapy. Dig Dis Sci 50: 949-954.

Mendes FR, Mattei R, Carlini ELA 2002. Activity of Hypericum brasiliense and Hypericum cordatum on the central nervous system in rodents. Fitoterapia 73: 462471.

Pellow S, Chopin P, File SE, Briley M 1985. Validation of open: closed arm entries in na elevated plus-maze as a measure of anxiety in the rat. $J$ Neurosc Meth 14: 149-167.

Pereda-Miranda R, Hernandez L, Villavicencio MJ, Novelo M, Ibarra P, Chai H, Pezzuto JM 1993. Structure and stereochemistry of pectinolides A-C, novel antimicrobial and cytotoxic 5,6-dihydro-pyrones from Hyptis pectinata. J Nat Prod 56: 583-593.

Porsolt R, Bertin A, Jalfre M 1977. Behavioural despair in mice. A preliminary screening test for antidepressants. Arch Int Pharmacodyn Ther 229: 217-227.

Puech AJ, Chermat R, Poncelet M, Doare L, Simon P 1981. Antagonism of hypothermia and behavioral response to apomorphine: a simple, rapid and discriminating test for screening antidepressants 
and neuroleptics. Psychopharmacol 75: 84-91.

Riley H, Spinks A 1958. Biological assesment of tranquilizers. J Pharma Pharmacol 10: 657-671.

Sousa FCF, Melo CTV, Monteiro AP, Lima VTM, Gutierrez SJC, Pereira BA, Barbosa-Filho JM, Vasconcelos SMM, Fonteles MF, Viana GSB 2004. Antianxiety and antidepressant effects of riparin III from Aniba riparia (Ness) (Lauraceae) in mice. Pharmacol Biochem Be 78: 27-33.

Thiessen DD 1988. Body temperature and grooming in the mongolian gerbil. Ann NY Acad Sci 525: 27-39.

Van-Erp AMM, Kruk MR, Meelis W, Willekens-Bramer C 1994. Effect of environmental stressors on time course, variability and form of self-grooming in the rat: handling, social contact, defeat, novelty, restraint and fur moistening. Behav Brain Res 65: 47-55. 